\title{
Anionic Sweet Tasting Derivatives of the Anti-Inflammatory Drug $\beta$-Glycyrrhetinic Acid
}

\author{
Toshinobu Toyoshima and Seizo Tamagaki \\ Department of Bioapplied Chemistry, Faculty of Engineering, Osaka City University \\ (3-3-138 Sugimoto, Sumiyoshi-ku, Osaka-shi, Osaka 558-8585)
}

\begin{abstract}
Anionic derivatives of $\beta$-glycyrrhetinic acid (GA) were prepared and assessed for sweetness. It was found that the presence of both a carboxyl group ( $\mathrm{COOH}$, free form) at $\mathrm{C} 20$ position and a carboxylate moiety $\left(\mathrm{COO}^{-}\right)$at $\mathrm{C} 3$ position in the GA molecule is essential for sweet taste. A plausible mechanism for sweet taste is proposed.

Key words : $\beta$-glycyrrhetinic acid, anionic derivatives, sulfates, sweet taste, sweetness mechanism
\end{abstract}

\section{Introduction}

There have been known a huge number of natural or synthetic sweet substances with low molecular weight : most mono- and oligo-saccharides, such as sucrose, D-glucose and D-fructose ; glycine; many D-amino acids; several L-amino acids, such as histidine, leucine, tyrosine, phenylalanine, and tryptophan ; others : $\mathrm{CHCl}_{3}$, nitrobenzene, benzimidazole, cyclamate, aspartame, saccharin $\operatorname{etc}^{1)}$. The sugars are now indispensable in our modern life. Among synthetic non-sugar sweeteners permitted as a food additive is aspartame $e^{2)}$, which is often utilized as a sugar substitute for a reducing diet in daily life and for therapeutical purposes.

Meanwhile, nature provides relatively large organic molecules exhibiting sweet taste, such as steviosides, dipotassium $\beta$-glycyrrhizinate (GK2, glycyrrhizin $)^{3)}$ and its monoglucronide derivative ${ }^{4)}$. Most of these compounds contain at least one glycosidic moiety in the molecule. Early work suggested that these natural sweet glycosides are all bifunctional, possessing two hydrophilic binding sites at both ends of the hydrophobic scafford ${ }^{5}$ ; namely, the synergistic weak nonbonding interactions may contribute to expression and enhancement of sweetness ${ }^{6}$. Of course, not only the appropriate hydrophile-lipophile balance but also the solubility-in-water of the target molecule

Corresponding author: Toshinobu ToYosHIMA seems important for a sweet tasting event. However, further certification should be demanded for the validity of this sweetness mechanism.

The traditional herbal medicine GK2, a natural sweet substance, has been recognized as a surfaceactive triterpenoid saponin with potent antiinflammatory and anti-allergic activities widely used today. However, there have been only a few reports on the structure-sweetness relationship for $\beta$-glycyrrhetinic acid (GA)-based sweetening agents ${ }^{4,7)}$, where GA is the highly hydrophobic aglycon of GK2. Potential significance of such GA-derived compounds as practical sweeteners shows promise for their utilization in food and pharmaceutical industries due to the nontoxicity. In order to develop a sweetener based on the GA, accordingly, at least some of the requirements mentioned above must be incorporated.

In this paper we will offer a definitive criterion for sweetness of GA derivatives, because a better understanding of the relationship between the sweetness and the chemical structures is of possible importance in developing new sweeteners.

\section{Experimental}

\section{Instruments.}

IR spectra were recorded on a Shimadzu FT-IR 8200 spectrometer. ${ }^{1} \mathrm{H}$-NMR spectra were measured using a Nihondensi Detum $\alpha$-400 spectrometer operating at $400 \mathrm{MHz}$. The FAB-MS spectra were recorded on a Nihon Bunko JMS7000 spectrometer. 


\section{General.}

Tetrahydrofuran (THF) was freshly distilled from sodium benzophenone ketyl. All other solvents were distilled after drying before use. Reagents were used as received. ${ }^{1} \mathrm{H}-\mathrm{NMR}$ spectra were obtained in $\mathrm{CDCl}_{3}$ or DMSO- $\mathrm{d}_{6}$ and chemical shifts were referenced to tetramethylsilane.

The benzylated and the acid compounds of the corresponding potassium salt are denoted by symbols, $-\mathrm{Bn}$ and $-\mathrm{H}$, respectively: for example, $1 \mathrm{~S}-\mathrm{Bn}$ and $1 \mathrm{~S}-\mathrm{H}$ for a potassium salt $1 \mathrm{~S}$. The symbols of other potassium compounds are indicated in Table 1 . All potassium salts that are summarized in Table 1 were obtained as precipitates by adding required amounts of $\mathrm{KOH}$ in $\mathrm{MeOH}$ to a solution of the corresponding carboxylic acids, and were characterized by comparing their IR and NMR spectra to those of the corresponding benzylated and /or acid precursors. The low resolution mass spectra of the potassium salts showed a molecular peak at the expected molecular weight. Generally, a carboxyl group(s), if necessary, was protected with a benzyl group, which was removed in the final step by $\mathrm{Pd}(\mathrm{OAc})_{2^{-}}$ or $10 \% \mathrm{Pd} / \mathrm{C}$-catalyzed hydrogenolysis that is a clean and efficient process. The procedures described below are representative.

GA-Benzyl ester (GA-Bn). GA was esterified by the reaction with a large excess of benzyl bromide in the presence of $\mathrm{K}_{2} \mathrm{CO}_{3}$ in refluxing acetone, followed by a usual work-up of the reaction mixture and recrystallization of the crude product from acetone/hexane, giving the title ester in $78.5 \%$ yield ; mp $129 \sim 131^{\circ} \mathrm{C},{ }^{1} \mathrm{H}-\mathrm{NMR}\left(\mathrm{CDCl}_{3}\right)$ $\delta: 0.74,0.81,1.00,1.11,1.14,1.16,1.42$ (each $3 \mathrm{H}$, each s, $\left.\mathrm{CH}_{3}\right), 3.23(1 \mathrm{H}, \mathrm{dd}, \mathrm{J}=6.9 \mathrm{~Hz}, \mathrm{CH}-$ $\mathrm{OH}), 5.07 \sim 5.22\left(2 \mathrm{H}, \mathrm{m}, \mathrm{Ph}-\mathrm{CH}_{2}\right), 5.55(1 \mathrm{H}, \mathrm{s}$, $\mathrm{C} 12-\mathrm{H}), 7.25 \sim 7.37(5 \mathrm{H}, \mathrm{m}, \mathrm{Ph})$.

3-Succinyloxy-GA (1S-H $)^{8)}$ and $1 \mathrm{~S}-\mathrm{Bn}$. GA was allowed to react with succinic anhydride in pyridine at $90^{\circ} \mathrm{C}$ for 5 days. The solution was concentrated and then acidified with aq. $\mathrm{HCl}$ to give the precipitates of $1 \mathrm{~S}-\mathrm{H}$. The crude product was recrystallized from $\mathrm{MeOH} / \mathrm{H}_{2} \mathrm{O}$ to give $1 \mathrm{~S}-\mathrm{H}$ in $52.0 \%$ yield; dec. $>300^{\circ} \mathrm{C}, \mathbb{I R}\left(\mathrm{cm}^{-1}\right) 1740$ $(\mathrm{COOCH}), 1705(\mathrm{COOH}), 1651(\mathrm{C}=\mathrm{C}-\mathrm{C}=\mathrm{O})$.

${ }^{1} \mathrm{H}-\mathrm{NMR}\left(\mathrm{CDCl}_{3}\right) \delta: 0.84,0.88,0.88,1.13,1.16$, $1.22,1.39$ (each $3 \mathrm{H}$, each s, C-CH${ }_{3}$ ), 2.15 2.19 $\left(4 \mathrm{H}, \mathrm{m}, \mathrm{CO}\left(\mathrm{CH}_{2}\right)_{2} \mathrm{COOH}\right), 4.56(1 \mathrm{H}, \mathrm{m}, \mathrm{CH}-$ $\mathrm{OH}), 5.69(1 \mathrm{H}, \mathrm{s}, \mathrm{C} 12-\mathrm{H})$. Similar treatment of
GA-Bn with succinic anhydride and recrystallization of the resulting product from $\mathrm{MeOH}$ gave $1 \mathrm{~S}$ $\mathrm{Bn}$ : yield $51.3 \%, \quad \mathrm{mp} 208 \sim 209^{\circ} \mathrm{C},{ }^{1} \mathrm{H}-\mathrm{NMR}$ $\left(\mathrm{CDCl}_{3}\right) \delta: 0.84,0.88,0.88,1.13,1.16,1.22,1.39$ (each $3 \mathrm{H}$, each s, C-CH $\mathrm{CH}_{3}, 2.15 \sim 2.19(4 \mathrm{H}, \mathrm{m}$, $\left.\mathrm{CO}\left(\mathrm{CH}_{2}\right)_{2} \mathrm{COOH}\right), 4.56(1 \mathrm{H}, \mathrm{m}, \mathrm{CH}-\mathrm{OH}), 5.69$ $(1 \mathrm{H}, \mathrm{s}, \mathrm{C} 12-\mathrm{H}) 7.25 \sim 7.37(5 \mathrm{H}, \mathrm{m}, \mathrm{Ph})$.

2S-, 3S-, 4S-, 5S- and 6S-H. General procedure. The title compounds were obtained by the reaction of $1 \mathrm{~S}-\mathrm{Bn}$ with a variety of amino acid benzyl ester toluenesulfonic acid salts in the presence of 1-ethyl-3-(3-dimethylaminopropyl)carbodiimide, 4-dimetylaminopyridine and triethylamine in $\mathrm{CH}_{2} \mathrm{Cl}_{2}{ }^{9}$ and the subsequent debenzylation in $\mathrm{MeOH} / \mathrm{THF}$ at $40^{\circ} \mathrm{C} ; 2 \mathrm{~S}-\mathrm{H}$ : yield $45.7 \%$, dec. $263 \sim 265^{\circ} \mathrm{C},{ }^{1} \mathrm{H}-\mathrm{NMR}$ (DMSO-d ${ }_{6}$ ) $\delta: 0.76$, $0.81,082,1.04,1.06,1.10,1.37$ (each $3 \mathrm{H}$, each $\mathrm{s}$, C- $\left.\mathrm{CH}_{3}\right), 3.67\left(2 \mathrm{H}, \mathrm{d}, \mathrm{Gly}-\mathrm{CH}_{2}\right), 4.43(1 \mathrm{H}, \mathrm{dd}, \mathrm{CH}-$ $\mathrm{OH}), 5.41(1 \mathrm{H}, \mathrm{s}, \mathrm{C} 12-\mathrm{H}), 8.08(1 \mathrm{H}$, br.s, N-H). MS Calcd for $\mathrm{C}_{36} \mathrm{H}_{53} \mathrm{NO}_{8}\left(\mathrm{M}^{+}\right)$627.4, Found 627 ; $3 \mathrm{~S}-\mathrm{H}$ : yield $24.8 \%, \mathrm{mp} 244 \sim 245^{\circ} \mathrm{C},{ }^{1} \mathrm{H}-\mathrm{NMR}$ $\left(\right.$ DMSO-d $\left._{6}\right) \delta: 0.75,0.80,082,1.04,1.06,1.10$, 1.36 (each $3 \mathrm{H}$, each s, C- $\left.\mathrm{CH}_{3}\right), 4.15(1 \mathrm{H}, \mathrm{m}, \mathrm{Ala}-$ $\mathrm{CH}), 4.40(1 \mathrm{H}, \mathrm{m}, \mathrm{CH}-\mathrm{OH}), 5.40(1 \mathrm{H}, \mathrm{s}, \mathrm{C} 12-\mathrm{H})$, $8.18(1 \mathrm{H}, \mathrm{d}, \mathrm{J}=7.6 \mathrm{~Hz}, \mathrm{~N}-\mathrm{H})$. MS Calcd for $\mathrm{C}_{37} \mathrm{H}_{55} \mathrm{NO}_{8}\left(\mathrm{M}^{+}\right)$641.4, Found 641.4; 4S-H : yield $76.4 \%$, dec. $251 \sim 254{ }^{\circ} \mathrm{C},{ }^{1} \mathrm{H}-\mathrm{NMR}$ (DMSO-d $\mathrm{d}_{6}$ ) $\delta$ : $0.76,0.81,082,1.04,1.06,1.10,1.37$ (each $3 \mathrm{H}$, each s, C-CH $\left.\mathrm{CH}_{3}\right), 4.31(1 \mathrm{H}, \mathrm{m}, \mathrm{Asp}-\mathrm{CH}), 4.41(1 \mathrm{H}$, m, Hz CH-OH), $5.41(1 \mathrm{H}, \mathrm{s}, \mathrm{C} 12-\mathrm{H}), 7.97(1 \mathrm{H}$, br.s, N-H). MS Calcd for $\mathrm{C}_{38} \mathrm{H}_{55} \mathrm{NO}_{10} \mathrm{Na}([\mathrm{M}+$ $\mathrm{Na}^{+}$) 708.3, Found 708.3 ; 5S-H : yield 39.2\%, mp $246 \sim 248^{\circ} \mathrm{C},{ }^{1} \mathrm{H}-\mathrm{NMR}$ (DMSO-d $\mathrm{d}_{6}$ ) $\delta: 0.81,0.87$, $088,1.13,1.23,1.24,1.40$ (each $3 \mathrm{H}$, each s, C$\left.\mathrm{CH}_{3}\right), 4.39 \sim 4.43(1 \mathrm{H}, \mathrm{m}, \mathrm{CH}-\mathrm{OH}), 5.40(1 \mathrm{H}, \mathrm{s}$, $\mathrm{C} 12-\mathrm{H}), 8.16(1 \mathrm{H}, \mathrm{d}, \mathrm{J}=8 \mathrm{~Hz}, \mathrm{~N}-\mathrm{H})$. MS Calcd for $\mathrm{C}_{39} \mathrm{H}_{57} \mathrm{NO}_{10}\left(\mathrm{M}^{+}\right) 699.4$, Found $699.4 ; 6 \mathrm{~S}-\mathrm{H}$ : yield $32.3 \%$, dec. $223 \sim 226^{\circ} \mathrm{C},{ }^{1} \mathrm{H}-\mathrm{NMR}$ (DMSO-d $\mathrm{d}_{6}$ ) $\delta$ : $0.75,0.85,086,1.04,1.06,1.08,1.36$ (each $3 \mathrm{H}$, each s, C-CH$)_{3}$, $3.69 \sim 3.74$ (4H, m, Gly-Gly-CH), $4.41(1 \mathrm{H}, \mathrm{dd}, \mathrm{J}=4$ and $8 \mathrm{~Hz}, \mathrm{~Hz} \mathrm{CH}-\mathrm{OH}), 5.44$ (1H, s, C12-H), $7.65(1 \mathrm{H}$, br.s, N-H). MS Calcd for $\mathrm{C}_{38} \mathrm{H}_{56} \mathrm{~N}_{2} \mathrm{O}_{9}\left(\mathrm{M}^{+}\right)$684.4, Found 684.4.

GA-methyl ester ${ }^{10)}$. GA was esterified with diazomethane in THF according to the method reported previously; yield $99.0 \%, \mathrm{mp} 239 \sim 242^{\circ} \mathrm{C}$, $\operatorname{IR}\left(\mathrm{cm}^{-1}\right)$ 1724, (COOMe), $1659(\mathrm{C}=\mathrm{C}-\mathrm{C}=\mathrm{O})$.

$8 \mathrm{~S}-\mathrm{H}$. For succinylation of GA-Me, the same method as employed for $1 \mathrm{~S}-\mathrm{Bn}$ was followed; yield $18.4 \%$, mp $270 \sim 271^{\circ} \mathrm{C},{ }^{1} \mathrm{H}-\mathrm{NMR}\left(\mathrm{CDCl}_{3}\right) \delta$ : 
Table1 Sweetness and Bitterness of Anionic GA-Derivatives ${ }^{\text {a) }}$.

\begin{tabular}{|c|c|c|}
\hline sweet group & tasteless group & bitter group \\
\hline$\frac{\mathrm{R}_{20}=\mathrm{CO}_{2} \mathrm{H}}{\mathrm{R}_{3}}$ & $\frac{\mathrm{R}_{20}=\mathrm{CO}_{2} \mathrm{Me}}{\mathrm{R}_{3}}$ & $\frac{\mathrm{R}_{3}=\mathrm{OH}}{\mathrm{R}_{20}}$ \\
\hline & $8 \mathrm{~S}$ & $12 \mathrm{~A}$ \\
\hline $\begin{array}{l}-\mathrm{OCO}\left(\mathrm{CH}_{2}\right)_{2} \mathrm{CO}_{2}^{-} \\
\quad(30)\end{array}$ & $-\mathrm{OCO}\left(\mathrm{CH}_{2}\right)_{2} \mathrm{CO}_{2}^{-\mathrm{b})}$ & $-\mathrm{CO}_{2} \mathrm{CH}_{2} \mathrm{CO}_{2}^{-}$ \\
\hline $2 \mathrm{~S}$ & & $13 \mathrm{~A}$ \\
\hline $\begin{array}{l}-\mathrm{OCO}\left(\mathrm{CH}_{2}\right)_{2} \mathrm{CONHCH}_{2} \mathrm{CO}_{2}^{-} \\
\quad(80) \\
3 \mathrm{~S}\end{array}$ & & $\begin{array}{r}-\mathrm{CO}_{2} \mathrm{CH}_{2} \mathrm{CONHCH}_{2} \mathrm{CO}_{2}^{-} \\
\text {(Gly) }\end{array}$ \\
\hline \multicolumn{3}{|l|}{$\begin{array}{c}-\mathrm{OCO}\left(\mathrm{CH}_{2}\right)_{2} \mathrm{CONHCHMeCO}_{2}^{-} \\
(50)\end{array}$} \\
\hline $4 \mathrm{~S}$ & $9 \mathrm{~S}$ & $14 \mathrm{~A}$ \\
\hline$-\mathrm{OCO}\left(\mathrm{CH}_{2}\right)_{2} \mathrm{CONHCHCO}_{2}^{-}$ & $-\mathrm{OCO}\left(\mathrm{CH}_{2}\right)_{2} \mathrm{CONHCHCO}_{2}^{-}$ & $-\mathrm{CO}_{2} \mathrm{CH}_{2} \mathrm{CONHCHCO}{ }^{-}$ \\
\hline $\begin{array}{c}\mathrm{CH}_{2} \mathrm{CO}_{2}^{-} \\
\text {(L-or D-Asp) }\end{array}$ & $\begin{array}{c}\mathrm{CH}_{2} \mathrm{CO}_{2}^{-} \\
\text {(L-Asp) }\end{array}$ & $\begin{array}{c}\mathrm{CH}_{2} \mathrm{CO}_{2}^{-} \\
\text {(L-or D-Asp) }\end{array}$ \\
\hline \multicolumn{3}{|l|}{$-\mathrm{OCO}\left(\mathrm{CH}_{2}\right)_{2} \mathrm{CONHCHCO}_{2}^{-}$} \\
\hline \multicolumn{3}{|l|}{\begin{tabular}{cl} 
(50) & $\mathrm{CH}_{2}$ \\
& \multicolumn{1}{c}{} \\
& $\mathrm{CH}_{2} \mathrm{CO}_{2}^{-}$ \\
& $(\mathrm{L}-\mathrm{Glu})$
\end{tabular}} \\
\hline $\begin{array}{l}6 \mathrm{~S} \\
-\mathrm{OCO}\left(\mathrm{CH}_{2}\right)_{2} \mathrm{CO}\left(\mathrm{NHCH}_{2} \mathrm{CO}\right)_{2} \mathrm{O}^{-} \\
\underset{7}{(100)} \quad(\text { Gly-Gly })\end{array}$ & & $\begin{array}{l}{ }_{-} \mathrm{CO}_{2} \mathrm{CH}_{2} \mathrm{CO}\left(\mathrm{NHCH}_{2} \mathrm{CO}\right)_{2} \mathrm{O} \\
\qquad(\mathrm{Gly}-\mathrm{Gly})\end{array}$ \\
\hline \multirow[t]{2}{*}{$\begin{array}{r}-\mathrm{OSO}_{3}^{-} \\
(150)\end{array}$} & $\begin{array}{l}10 \\
-\mathrm{OSO}_{3}^{-\mathrm{c}}\end{array}$ & \\
\hline & $\begin{array}{l}11 \mathrm{~A} \\
\mathrm{R}_{3}=-\mathrm{OSO}_{3}^{-} \\
\mathrm{R}_{20}=\mathrm{CO}_{2} \mathrm{CH}_{2} \mathrm{CO}_{2}^{-}\end{array}$ & \\
\hline
\end{tabular}

The numbers in parentheses denote the relative sweetness potency of the GA-derivatives to $4 \%$ sucrose.

a) as potassium salts. b) sparingly soluble in water. c) slighty soluble in water.

$0.84,0.88,0.88,1.13,1.16,1.22,1.39$ (each $3 \mathrm{H}$, each s, $\left.\mathrm{C}-\mathrm{CH}_{3}\right), 2.15 \sim 2.19\left(4 \mathrm{H}, \mathrm{m}, \mathrm{CO}\left(\mathrm{CH}_{2}\right)_{2}\right.$ $\mathrm{COOH}), 3.70(3 \mathrm{H}, \mathrm{s}, \mathrm{COOMe}), 4.56(1 \mathrm{H}, \mathrm{m}, \mathrm{CH}-$ $\mathrm{OH}), 5.69(1 \mathrm{H}, \mathrm{s}, \mathrm{C} 12-\mathrm{H})$. MS Calcd for $\mathrm{C}_{35} \mathrm{H}_{52} \mathrm{O}_{7}$ $\left(\mathrm{M}^{+}\right)$584.4, Found 584.4.

9S-H. 8S-H was coupled with L-aspartic acid $\alpha, \beta$-dibenzyl ester and the product thus obtained was subjected to debenzylation; yield $91.4 \%, \mathrm{mp}$ $180 \sim 182^{\circ} \mathrm{C},{ }^{1} \mathrm{H}-\mathrm{NMR}$ (DMSO-d ${ }_{6}$ ) $\delta: 0.78,0.85$, $086,1.08,1.10,1.11,1.40$ (each $3 \mathrm{H}$, each s, C$\left.\mathrm{CH}_{3}\right), 3.64(3 \mathrm{H}, \mathrm{s}, \mathrm{COOMe}), 4.43 \sim 4.47(1 \mathrm{H}, \mathrm{m}$, $\mathrm{Hz} \mathrm{CH}-\mathrm{OH}), 5.46$ (1H, s, C12-H), 7.65 (1H, br.s, $\mathrm{N}-\mathrm{H})$. MS Calcd for $\mathrm{C}_{39} \mathrm{H}_{57} \mathrm{NO}_{10}\left(\mathrm{M}^{+}\right)$699.4, Found 699.4.

12A-H. The $\mathrm{C} 20-\mathrm{COOH}$ terminal of GA was extended by reaction with benzyl bromoacetate in the presence of $\mathrm{K}_{2} \mathrm{CO}_{3}$ in refluxing acetone, affording GA-COOCH${ }_{2} \mathrm{COOBn}$ (12A-Bn : yield $79.4 \%, \mathrm{mp} 109 \sim 111^{\circ} \mathrm{C}$ ), which was debenzylated with $10 \% \mathrm{Pd} / \mathrm{C}-\mathrm{H}_{2}$ in $\mathrm{MeOH} / \mathrm{THF}$; yield $38.4 \%$, mp $277 \sim 278^{\circ} \mathrm{C},{ }^{1} \mathrm{H}-\mathrm{NMR}\left(\mathrm{DMSO}-\mathrm{d}_{6}\right) \quad \delta: 0.69$, $0.76,0.91,1.02,1.03,1.14,1.35$ (each $3 \mathrm{H}$, each $\mathrm{s}$, $\left.\mathrm{CH}_{3}\right), 4.54 \sim 4.67$ (2H, m, COO- $\left.\mathrm{CH}_{2} \mathrm{COOH}\right), 5.48$ $(1 \mathrm{H}, \mathrm{s}, \mathrm{C} 12-\mathrm{H})$. MS Calcd for $\mathrm{C}_{32} \mathrm{H}_{48} \mathrm{O}_{6}\left(\mathrm{M}^{+}\right)$ 528.3, Found 528.3.

13A-H, 14A-H, 15A-H. The title compounds were obtained by reaction of $12 \mathrm{~A}-\mathrm{H}$ with C-benzyl protected amino acid toluenesulfonic acid salts in the presence of 1-ethyl-3-(3-dimethylaminpropyl) carbodiimide, 4-dimethylaminopyridine and tri- 


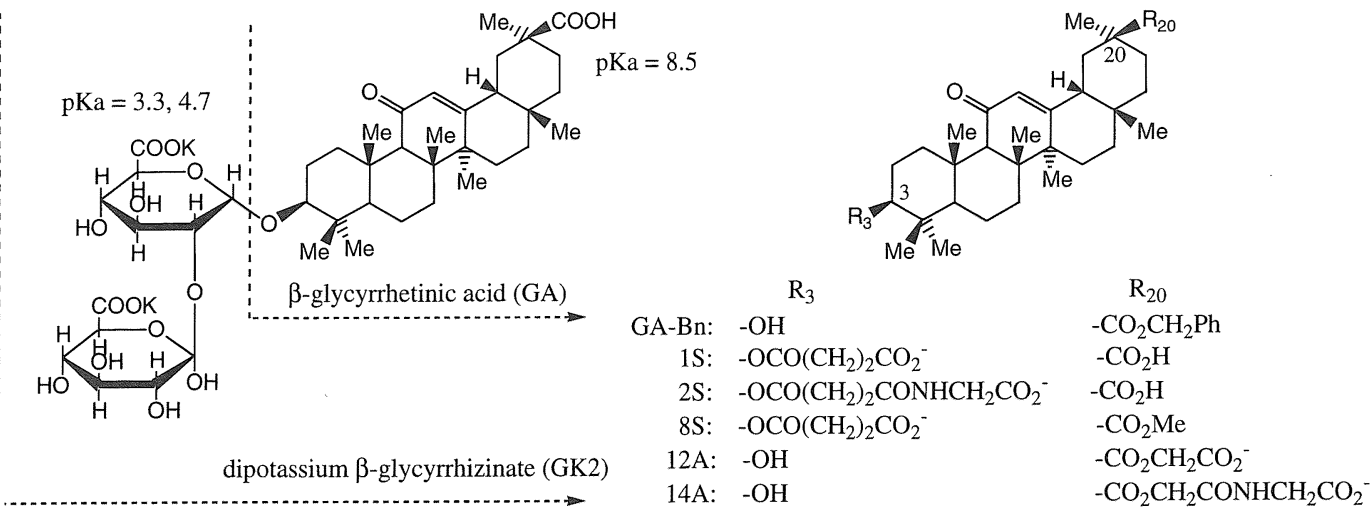

Fig. 1 GA and Its Related Derivatives.

ethylamine in $\mathrm{CH}_{2} \mathrm{Cl}_{2}$, followed by deprotection with $10 \% \mathrm{Pd} / \mathrm{C}$ at $40^{\circ} \mathrm{C}$ under hydrogen for $1 \mathrm{~h}$ in $\mathrm{MeOH} / \mathrm{THF} ; 13 \mathrm{~A}-\mathrm{H}$ : yield $48.6 \%$, mp $240 \sim$ $244^{\circ} \mathrm{C},{ }^{1} \mathrm{H}-\mathrm{NMR}\left(\mathrm{CDCl}_{3}\right) \delta 0.69,0.76,0.91,1.03$, $1.04,1.15,1.35$ (each $3 \mathrm{H}$, each s, C-CH $)_{3}, 3.01$ $(1 \mathrm{H}, \mathrm{dd}, \mathrm{CH}-\mathrm{OH}) 3.80(2 \mathrm{H}, \mathrm{d}, \mathrm{J}=6 \mathrm{~Hz}, \mathrm{Gly}-$ $\left.\mathrm{CH}_{2}\right), 4.50 \sim 4.64\left(2 \mathrm{H}, \mathrm{m}, \mathrm{COO}-\mathrm{CH}_{2}-\mathrm{CO}\right), 5.48$ $(1 \mathrm{H}, \mathrm{s}, \mathrm{C} 12-\mathrm{H}), 8.29(1 \mathrm{H}, \mathrm{t}, \mathrm{J}=6 \mathrm{~Hz} \mathrm{~N}-\mathrm{H}) . \mathrm{MS}$ Calcd for $\mathrm{C}_{34} \mathrm{H}_{51} \mathrm{NO}_{7}\left(\mathrm{M}^{+}\right)$585.4, Found 585.4 ; $14 \mathrm{~A}-\mathrm{H}$ : yield $67.2 \%, \mathrm{mp} 200 \sim 202^{\circ} \mathrm{C},{ }^{1} \mathrm{H}-\mathrm{NMR}$ $\left(\right.$ DMSO-d $\left._{6}\right) \delta: 0.69,0.76,091,1.02,1.04,1.15$, 1.35 (each $3 \mathrm{H}$, each s, $\left.\mathrm{C}-\mathrm{CH}_{3}\right), 4.49 \sim 4.63(2 \mathrm{H}, \mathrm{m}$, $\left.\mathrm{COO}-\mathrm{CH}_{2}-\mathrm{CO}\right), 5.49(1 \mathrm{H}, \mathrm{s}, \mathrm{C} 12-\mathrm{H}), 8.28(1 \mathrm{H}, \mathrm{d}$, $\mathrm{J}=8 \mathrm{~Hz}, \mathrm{~N}-\mathrm{H})$. MS Calcd for $\mathrm{C}_{36} \mathrm{H}_{53} \mathrm{NO}_{9}\left(\mathrm{M}^{+}\right)$ 643.4, Found $643.4 ; 15 \mathrm{~A}-\mathrm{H}$ : yield $45.1 \%$, mp 162 $\sim 164^{\circ} \mathrm{C},{ }^{1} \mathrm{H}-\mathrm{NMR}$ (DMSO-d $\left.{ }_{6}\right) \delta: 0.68,0.75,0.90$, $1.02,1.03,1.14,1.35$ (each $3 \mathrm{H}$, each $\mathrm{s}, \mathrm{C}-\mathrm{CH}_{3}$ ), $4.50 \sim 4.65\left(2 \mathrm{H}, \mathrm{m}, \mathrm{COO}-\mathrm{CH}_{2}-\mathrm{CO}\right), 5.47(1 \mathrm{H}, \mathrm{s}$, C12-H), 8.28 (1H, br.s, N-H). MS Calcd for $\mathrm{C}_{36} \mathrm{H}_{54} \mathrm{~N}_{2} \mathrm{O}_{8}\left(\mathrm{M}^{+}\right)$642.4, Found 642.4.

7, 10, 11A. GA, GA-Me, and 12A-H were sulfated with three to five equivalents of $\mathrm{SO}_{3}$. pyridine complex in THF. The resulting precipitates were filtered off and washed with THF. The dissolution of the precipitates in $\mathrm{MeOH}$, followed by neutralization to $\mathrm{pH} 8$ with a $2 \mathrm{M} \mathrm{KOH}$ solution in $\mathrm{MeOH}$, removal of precipitated $\mathrm{K}_{2} \mathrm{SO}_{4}$ and purification of the crude products, eventually gave the GA-sulfate dipotassium salt 7, the GA-Mesulfate monopotassium salt 10 , and the $12 \mathrm{~A}$-sulfate dipotassium salt $11 \mathrm{~A}$, respectively; salt $7:$ yield $8.3 \%$, dec. $265 \sim 270^{\circ} \mathrm{C}, \mathrm{IR}\left(\mathrm{cm}^{-1}\right) 1653(\mathrm{C}=\mathrm{C}-\mathrm{C}$ $=\mathrm{O}), 1558(\mathrm{COOK}) .{ }^{1} \mathrm{H}-\mathrm{NMR}$ (DMSO-d 6 ) $\delta$ : $0.69,0.71,0.75,0.78,1.03,1.04,1.40$ (each $3 \mathrm{H}$, each s, $\left.\mathrm{C}-\mathrm{CH}_{3}\right), 3.71 \sim 3.76(1 \mathrm{H}, \mathrm{m}, \mathrm{CH}-\mathrm{OH}), 5.50$
$(1 \mathrm{H}, \mathrm{s}, \mathrm{C} 12-\mathrm{H})$. MS Calcd for $\mathrm{C}_{30} \mathrm{H}_{45} \mathrm{O}_{7} \mathrm{SK}_{2}([\mathrm{M}+$ $\mathrm{H}]^{+}$) 627.2, Found 627.2 ; Salt 10 : yield $17.9 \%$, mp $240 \sim 242^{\circ},{ }^{1} \mathrm{H}-\mathrm{NMR}\left(1 \% \mathrm{CD}_{3} \mathrm{OD}-\mathrm{CDCl}_{3}\right) \delta$ : $0.80,0.82,1.03,1.11,1.14,1.15,1.37$ (each $3 \mathrm{H}$, each s, C- $\left.\mathrm{CH}_{3}\right), 3.98 \sim 4.00(1 \mathrm{H}, \mathrm{m}, \mathrm{CH}-\mathrm{OH}), 5.64$ $(1 \mathrm{H}, \mathrm{s}, \mathrm{C} 12-\mathrm{H})$. MS Calcd for $\mathrm{C}_{31} \mathrm{H}_{48} \mathrm{O}_{7} \mathrm{SK}$ ([M+ $\left.\mathrm{H}]^{+}\right)$603.3, Found 603.3, $\mathrm{C}_{31} \mathrm{H}_{47} \mathrm{O}_{7} \mathrm{SK}_{2}\left([\mathrm{M}+\mathrm{K}]^{+}\right)$ 641.2 , Found 641.2 ; Salt 11A : yield $18.4 \%$, dec. $271 \sim 275^{\circ} \mathrm{C},{ }^{1} \mathrm{H}-\mathrm{NMR}$ (DMSO-d ${ }_{6}$ ) $\delta: 0.69,0.75$, $0.78,0.92,1.03,1.04,1.35$ (each $3 \mathrm{H}$, each s, C$\left.\mathrm{CH}_{3}\right), 3.62 \sim 3.67(1 \mathrm{H}, \mathrm{m}, \mathrm{CH}-\mathrm{OH}), 4.00 \sim 4.20$ $\left(2 \mathrm{H}, \mathrm{m}, \mathrm{COO}-\mathrm{CH}_{2}-\mathrm{CO}\right), 5.53(1 \mathrm{H}, \mathrm{s}, \mathrm{C} 12-\mathrm{H}) . \mathrm{MS}$ Calcd for $\mathrm{C}_{32} \mathrm{H}_{46} \mathrm{O}_{9} \mathrm{SK}_{2}\left([\mathrm{M}+\mathrm{K}]^{+}\right)$685.2, Found $685.2 ; \mathrm{C}_{32} \mathrm{H}_{46} \mathrm{O}_{9} \mathrm{SK}_{3}\left([\mathrm{M}+\mathrm{K}]^{+}\right)$723.2, Found 723.2.

The chemical structures of GA, GK2, and some related compounds are presented in Fig. 1 .

\section{Results and Discussion}

In order to find out essential elements causing sweetness to anionic derivatives of $\beta$-glycyrrhetinic acid (GA), in the present work we have synthesized different types of compounds attaching one or two carboxyl substituents (R3, R20) such as a variety of amino acid residues in the $\mathrm{C}-3 \mathrm{and} /$ or $\mathrm{C}$ 20 positions of the hydrophobic triterpen-backbone through an ester or amide linkage (Table 1). As anticipated, all the materials thus obtained were considerably surface-active except poorly soluble compound $8 \mathrm{~S}\left(\mathrm{R} 3\right.$ : $\mathrm{OCO}\left(\mathrm{CH}_{2}\right)_{2} \mathrm{CO}_{2}{ }^{-}, \mathrm{R} 20$ : $\mathrm{CO}_{2} \mathrm{Me}$ ). The utilization of $\mathrm{GA}$ as a starting material has several advantages: GA itself is cheap and is easily modified through the $\mathrm{OH}$ and $\mathrm{COOH}$ functional groups; the GA-derivatives thus obtained would be susceptible to hydrolysis under physiological conditions and then be 
probably nontoxic. Thus, our major concern in this study is to know whether or not the anionic GAderivatives so formed exhibit sweetness and to delineate the sweetness mechanism. Generally, the sweet taste of a molecule can be easily assessed by tasting it with the tongue.

Rough sweetness assessment has been performed with 15 samples, which tastes range from the sweet to the bitter. The results thus obtained are summarized in Table 1. Inspection of the table reveals that, generally, the compounds containing one easily ionizable carboxyl group ( $\mathrm{pKa}: 4-5)$ at the $\mathrm{C}-3$ position of GA were all sweet, and such sweet characters were independent of the spacer length and the number of anionic charges of the side chains (entries $1 \mathrm{~S}-6 \mathrm{~S}, 7$ ). Furthermore, in contrast to a large difference in sweet taste between $\mathrm{D}$ - and L-amino acid enantiomers themselves, no distinct difference was recognized between GA-derivatives bearing the corresponding $\mathrm{D}$ - and L-amino acid residues (entries $4 \mathrm{~S}$ and $14 \mathrm{~A}$ ), indicating the response of the taste bud receptor toward chirality being essentially nonselective.

However, the methyl esterification of the C-20 carboxyl group $(\mathrm{COOH})$ of the above compounds $1 \mathrm{~S}$ and $4 \mathrm{~S}$ resulted in a tastelessness (entries $8 \mathrm{~S}$ and 9S), strongly suggesting that the presence of the relatively less ionizable $\mathrm{C}-20 \mathrm{COOH}$ moiety (pka : 8.5) is also substantial for the expression of sweetness; taking the physiological $\mathrm{pH}$ value of the salivary solution being 7.1 into consideration, the $\mathrm{C}-3$ and $\mathrm{C}-20 \mathrm{COOH}$ groups on the GA hydrophobic scaffold of these sweet molecules predominantly exist as the ionized and the free form, respectively. We undoubtedly conclude, therefore, that there exist at least two different types of polar binding sites in the sweet taste receptor. These distal binding sites are placed more than $13 \AA$ apart, since GA has the hydrophobic part of $13 \AA$ long ${ }^{11}$.

Hence, we can infer, in agreement with the above observation and presumption, that there exist two different receptive binding sites, separating each other at a large distance, that would bind a stimulant molecule through electrostatic attractions such as hydrogen-bonding, charge-charge and/or charge-dipole interactions : most possibly, one is acting as a proton acceptor (B) comprising basic side-chain functionality such as $-\mathrm{COO}^{-}$or $-\mathrm{NH}_{2}$, while the other as a proton donor $(\mathrm{AH})$ comprising acidic functionality such as $\mathrm{COOH}$ or $-\mathrm{NH}_{3}{ }^{+}$on the protein surface. Some nearby $\mathrm{OH}$ groups also may participate in binding the stimulant molecule.

According to this inference, we can understand the tastelessness of a dianionic and hydrophilic compound (entry 11A). Its tastelessness may be mainly attributed to a lack of a proton donation group in the molecule. Meanwhile, increased hydrophobicity of a stimulant molecule will impart a bitter taste. Actually, rather hydrophobic compounds (entries $12 \mathrm{~A}-15 \mathrm{~A}$ ) exhibited a bitter taste; these molecules commonly possess at least one proton accepting carboxylate moiety at the C20 position alone but with no proton donor group except the $\mathrm{C}-3 \mathrm{OH}$ group that is too weak for a proton donor. It is well documented that, when a stimulant molecule binds to the receptor embedded in the cell membrane, the depolarization of a membrane potential is developed ${ }^{12}$. The electric stimulus thus generated will be eventually trans-

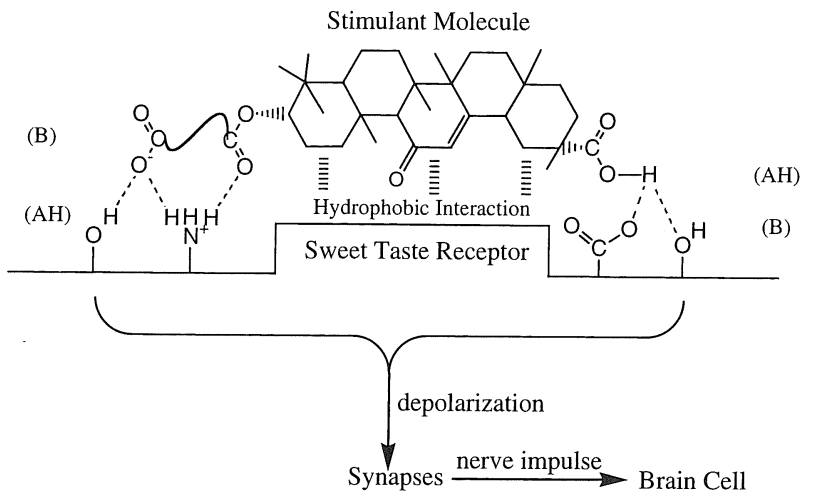

Fig. 2 Plausible Nonbonding Multiple Interactions Expressing a Sweet Taste. 


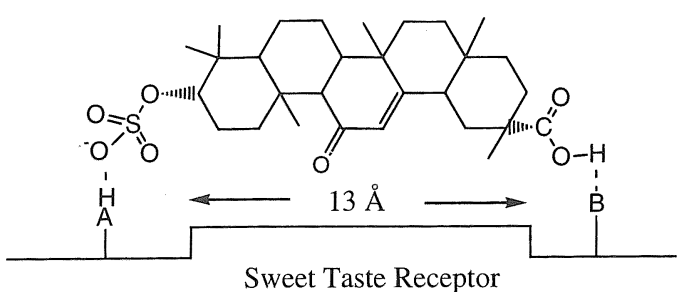

Fig. 3 The AH, B System for the Sulfated GA.

mitted as a nerve impulse to the brain cell via the chemical synapse. The oversimplified conceptual diagram is depicted in Fig 2.

Previously, Shallenberger and co-workers proposed that the unit common to sweet tasting compounds is a complementary, bifunctional $\mathrm{AH} / \mathrm{B}$ system where $\mathrm{A}$ and $\mathrm{B}$ are electronegative atoms separated by a distance of greater than 2.5 $\AA$, but less than $4 \AA^{13)}$. This $\mathrm{AH} / \mathrm{B}$ molecular theory has often been employed as a guide for designing the structures of sweet substances ${ }^{14)}$. However, as the entry 7 in Table 1 shows, the sulfated GA prepared by reaction of GA with $\mathrm{SO}_{3}$ - pyridine complex elicited strong sweetness, although the sulfate group itself has the proton accepting component (B), but lacks a well-defined proton donating component $(\mathrm{AH})$ within a distance of $4 \AA$. This observation also supports the forementioned suggestion that the $\mathrm{C}-20 \mathrm{COOH}$ group should act as the proton donating component (AH) (Fig. 3); in fact, when the sulfated GA(entry 7) was methylated at its $\mathrm{C}-20 \mathrm{COOH}$ group, it lost the sweetness entirely (entry 10). Furthermore, inspection of the molecular structural feature of the sulfated GA suggests that the pockets of the sweet taste receptor are rather shallower in depth than anticipated.

In conclusion, the systematic study of the structure-function relationship for the sweet tasting anionic GA derivatives allowed us to elucidate the molecular mechanism of the sweetness. This study will serve basic information for the future discoveries of new sweetening substances. (Received May 15, 2000 ; Accepted Jul. 27, 2000)

\section{References}

1) E.I. George(ed.), "Symposium: Sweeteners", The
Avi Publishing Company, Inc., Westport Connecticut, chapter 1 (1974) ; R.S. Shallenberger, T.E. Acree, Nature, 216, 480 (1967) ; J.W. Finley, M. Friedman, J. Agr. Food Chem., 21, 33 (1973).

2) R.H. Mazur, J.M. Schlater, A.H. Goldkamp, $J$. Am. Chem. Soc., 91, 2684 (1969).

3) Maruzen Pharmaceuticals Co. LTD, Dipotassium Glycyrrhizinate, p.8, March (1994).

4) T. Kuramoto, Y. Ito, M. Oda, Y. Tamura, S. Katahara, Biosci. Biotech. Biochem., 58, 455 (1994) ; T. Kuramoto, Y. Tamura, N. Ohtake, S. Doi, N. Nakamura, O. Tanaka, Biosci. Biotech. Biochem., 58, 554 (1994) ; K. Mizutani, T. Kambara, Y. Tamura, T. Ikeda, O. Tanaka, M. Takasaki, T. Konoshima, "Towards Natural Medicine Research in the 21st Century", H. Ageta, N. Aimi, Y. Ebizuka, T. Fujita, G. Honda, (eds.), Elsevier, Amsterdam, p.225 (1998).

5) Nihonkagakukai (ed.), "Aji to Nioi no Bunsininshiki", Kikan Kagaku Sosetu, No.40, Gakkai Shuppan Center, Tokyo, chapter 2, pp.35-49 (1999).

6) R.S. Shallenberger, T.E. Acree, J. Agric. Food Chem., 17, 701 (1969) ; E.I. George(ed.), "Symposium : Sweeteners", The Avi Publishing Company, Inc., Westport Connecticut, chapter 20 (1974).

7) R. Nakamura, H. Amino, T. Takamoto (Ajinomoto Co. LTD.), Japan Kokai, 1999-11-131 : Cationic amino acid derivatives of GA.

8) S. Tamagaki, T. Toyoshima, J. Jpn. Oil. Chem. Soc., 47, 765 (1998).

9) T. Mizoguchi, G. Levin, D.W. Woolley, J.M. Stewart, J. Org. chem. 33, 903 (1968).

10) S. Tamagaki, T. Toyoshima, J. Jpn. Oil. Chem. Soc., 48, 1282 (1999).

11) S. Tamagaki, M. Koide, M Takahashi, T. Mizushima, J. Ukawa, W. Tagaki, J. Chem. Soc., Perkin Trans. 2, 1257 (1996).

12) K. Tonosaki, M. Funakoshi, Nature, 331, 354 (1988) ; S.J. Bernhardt, M. Naim, U. Zahavi, B. Lindemann, J. Physiol. (London), 490, 325 (1996). Nihonkagakukai (ed.), "Aji to Nioi no Bunsininshiki”, Kikan Kagaku Sosetu, No.40, Gakkai Shuppan Center, Tokyo, pp.7-10 (1999).

13) R.S. Shallenberger, T.E. Acree, W.E. Guild, $J$. Food Sci., 30, 560 (1965).

14) T. Machinami, The Optimization of Sweet Taste Quality Meeting, September 27-28, Viareggio, Italy, Abstract, p.8 (1999). 


\title{
オーストラリア産ボラの卵塩乾物の ワックスエステル含量と組成
}

\author{
林賢治 ・ 岸村栄 毅 \\ 北海道大学大学院水産科学研究科 \\ （厂 041-8611 北海道函館市港町 3-1-1）
}

オーストラリア産ボラ(Mugil cephalus) の卵塩蔵物とその塩乾物(カラスミ)の脂質成分を明らかにした。両者 の脂質 $(\mathrm{TL})$ 含有率は，乾燥重量の 30.6 ～31.6\%であり， $\mathrm{C}_{32}$ および $\mathrm{C}_{34}$ を主成分 $(53.1 \sim 61.1 \%)$ とするワックス エステル (WE：82.8〜84.3\%) を含有した。WEの脂肪アルコールは，16:0 (59.3〜63.4\%)を主成分とする飽 和成分 $(83.5$ ～86.4\%) が特徵的であった。モノエン成分 $(11.9$ ～15.0\%) はいずれも二重結合位置異性体を含み， $16: 1 n-7(5.8 \sim 9.2 \%)$ が主成分であった。また，15:0 (3.1〜12.0\%)などの奇数炭素成分が存在した。WEの 構成脂肪酸は，16:1n-7 酸 (34.0〜 38.8\%) などのモノエン酸 $(56.1 〜 60.6 \%)$ および $20: 5 n-3$ 酸，22: $5 n-3$ 酸， $22: 6 \mathrm{n}-3$ 酸などのポリエン酸 $(26.6$ 31.1\%)を多量に含有したが, トリアシルグリセリン (TG)では $16: 0$ 酸 $(32.9 \sim 34.6 \%) ， 16: 1 n-7$ 酸 $(16.6 \sim 22.5 \%) ， 18: 1 n-7$ 酸 $(7.8 \sim 8.7 \%)$ が特徴的であった。また，酸化による ボラ卵塩乾物の TL，WE，TGのポリエン酸の減少は認められなかった。

（連絡者：林 賢治） Vol.49, No.11, 1401（2000）

\section{[報文］}

\section{抗炎症薬 $\beta$-グリシルレチン酸の アニオン型甘味誘導体}

豊 嶋 俊 薰 ・玉 垣 誠三 大阪市立大学工学部生物応用化学科

（テ558-8585 大阪府大阪市住吉区杉本 3-3-138）

$\beta$-グリシルレチン酸（GA）のアニオン型誘導体を多数合成し，それらの甘味を評価したところ，GAの 20 位 カルボキシル基 $(\mathrm{COOH})$ と 3 位の解離型アニオン置換基 $\left(\mathrm{COO}^{-}\right)$が甘味に必要であることが分かり, 甘味発現 機構を提案した。

(連絡者：豊嶋俊薰） Vol.49, No.11, 1407 (2000) 